\title{
耳覆い形および挿耳形イヤホンを用いた 健聴耳の語音了解間値（SRT）
}

\author{
荻野真愛 ${ }^{1)}$, 松平登志正 ${ }^{2)}$ \\ ${ }^{1)}$ 石岡循環器科脳神経外科病院 \\ 2) 北里大学医療衛生学部
}

\begin{abstract}
要旨:耳覆い形イヤホン (SENNHEISER HDA 200 型) および挿耳形イヤホン (EARTONE 3A 型）について, 語音聴力検查の基準值の設定を目的に, 30名の耳科学的正常者を対象 に 67-S 数字語表の語音了解閾值（SRT）を測定し, 耳載せ形イヤホン（Rion AD-02 型） と比較した。デー夕は, 各被験者が3つの異なるイヤホンで検査を受ける被験者内計画で 収集した。しかし, デー夕の分析過程で 2 回目, 3 回目の測定で一部順序効果による SRT の低下が認められたので, それぞれのイヤホンで最初に検査された 10 名からなる 3 グルー プの被験者間計画として再分析を行った。その結果, 耳覆い形と挿耳形イヤホンによる10 名の SRTの平均は, それぞれ 8.9dBSPL および 9.1dBSPLであったのに対して, 耳載せ 形のそれは, $13.7 \mathrm{dBSPL}$ と既存の基準值 14dBSPL に近い值が得られた。今回得られた 3 種のイヤホンの SRT は, 純音の基準等価閾值音圧レベルとの整合性が確認された。SRT の基準値の設定には，被験者数と実施施設を増やして被験者間計画により新たに検討を行 う必要があると考えられた。
\end{abstract}

$$
\text { ーキーワードー }
$$

耳覆い形イヤホン, 挿耳形イヤホン, 語音了解閾值, 基準語音了解閾值レベル, 67-S 語表

\section{はじめに}

現在，臨床における聴力検查に使用するイヤホン は，耳玠上に圧定するタイプの耳載せ形イヤホンの みが日本工業規格 $(\mathrm{JIS})^{1)}$ に基準レベルが規定され 一般に使用されている。一方，近年，耳介を包み込 むタイプの耳覆い形イヤホンや， レシーバの出力音 をチューブと耳せんを介して外耳道に導き聴取する 挿耳形イヤホンの出力音圧の較正法が確立され，基 準等価域值音圧レベルが規定されている23)。これを 受けて，わが国でも近く予定されている，オージオ メータの JIS の改正により, 耳覆い形イヤホンおよ び扱耳形イヤホンの使用が可能となる。

耳覆い形と抻耳形イヤホンについてはこれまで, 耳載せ形イヤホンに比べて遮音特性に優れている4)
ため実際の臨床現場のような暗騒音がある程度以上 存在する環境での聴力検査に有利である, 検查結果 の再現性が良( ${ }^{5 / 6)}$, 両耳間移行減衰量が大き( ${ }^{7 / 899)}$ ので聴力検査を行う際に陰影聴取が起こりにくくマ スキング不要の場合が増える等の利点が報告されて いる。そのため, 今後これらのイヤホンの使用され

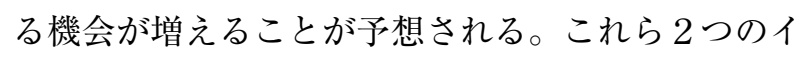
ヤホンは純音聴力検査の基準值は標準化されている が, 本邦で使用されている語音聴力検査語表の基準 值は報告されていない。語音聴力検査の結果を機種 の異なるイヤホン間で比較する場合, 同じ聴力レベ ルでの比較が必要となるが, これには, 基準レベル を求めておくことが必要である。そこで, この 2 種 のイヤホンについて基準值の設定を目的に, 健常成 人の語音了解閾值（SRT）を測定した。 


\section{対象と方法}

\section{1. 被験者と検查素材}

19歳から29歳（平均21.6歳，中央值21歳）の男女 30名（男 2 名, 女28名）を対象とした。被験者は, 耳疾患の症状所見が無く，耳垢栓塞もなく，過度の 騒音にさらされた経験もない正常な健康状態の人 $(\text { 耳科学的正常者 })^{1)}$ で, 純音聴力間值が $250 \mathrm{~Hz}$ $4000 \mathrm{~Hz}$ の各周波数において $20 \mathrm{~dB}$ 以下であり， か つティンパノグラムが $\mathrm{A}$ 型でピークが $\pm 50 \mathrm{daPa}$ 以 内にあることが確かめられた者 ${ }^{10)}$ とした。被験者に は本研究の趣旨を口頭で説明し同意を得た。

SRTの測定には，わが国の語音聴力検査の基準 レベルの決定に使用された日本聴覚医学会 67-S 数 字語表と，それらの行の順序を入れ替えて作った 4 表の計 5 表を用意し，それらを収録した CD を使用 した。後者のうち 2 表は予備として用いた。

2. 測定環境とイヤホン

測定は防音室内で行った。事前に暗騒音を測定 し, ISO 8253-1 ${ }^{11)}$ に規定されている，「125Hz 以上 の気導純音聴力閾值を $0 \mathrm{dBHL}$ まで $2 \mathrm{~dB}$ 以内の精度 で測定する場合の許容基準」を満たしていることを 確認した。

今回の実験では，耳覆い形イヤホンは SENNHEISER HDA 200 型，挿耳形イヤホンは EAR TONE 3 A 型を用いて, いずれも右耳で測定を行った。これ らに加え, 従来の耳載せ形イヤホン RION AD-02 型でも同様の測定を行った。各イヤホンの $100 \mathrm{mV}$
の定電圧特性の測定結果を図 1 に示す。

3. SRT の測定

各被験者に 3 種類のイヤホンを用いて SRTを測 定し，その際順序効果を相殺するため，測定するイ ヤホンの順序は 3 種のイヤホン間で釣りあわせた (counter-balance)。測定方法は語音聴力検査法 $(2003)^{12)}$ に従った。通常の語音聴力検査と同様に, $\mathrm{CD}$ プレーヤーの出力をオージオメータ RION AA71 型の外部入力端子に接続し, 各イヤホンをオー ジオメータの気導出力端子に接続して検査を行っ た。

SRT は明暸度が $50 \%$ となったレベルとし，その 算出方法は, 明瞭度曲線が $50 \%$ を横切る音のレベル を比例配分で求める方法（以下比例配分法と略称） と, ISO 8253-3 $3^{13)}$ に採用されているWilson らの方 法 $^{14)}$ (以下 Wilson 法と略称）の 2 つ算出方法を 用いた。後者では，SRTを以下の式より算出した。

$\mathrm{SRT}=\mathrm{Ls}-5 \mathrm{r} / 6+2.5$

ここで，Ls は正答率が100\%となった語音のレべ ル，r は Lsから正答率が $0 \%$ となるまで（1つの レベルで 6 語を提示し） $5 \mathrm{~dB}$ ステップで語音レベル を下げて検査を行った時の全正答数を表わす。

67-S 数字語表 $\mathrm{CD}$ に収録されている $1000 \mathrm{~Hz}$ 基準 音をオージオメータのダイヤル值 $60 \mathrm{~dB}$ で再生し, 耳載せ形・耳覆い形イヤホンについては人工耳（B \&K4153）を, 挿耳形イヤホンについては $2 \mathrm{~cm}^{3} カ$ プラ（B\&K4152）を用いて出力音圧の較正を行っ た。これを元に, SRTに相当する音圧レベルを求

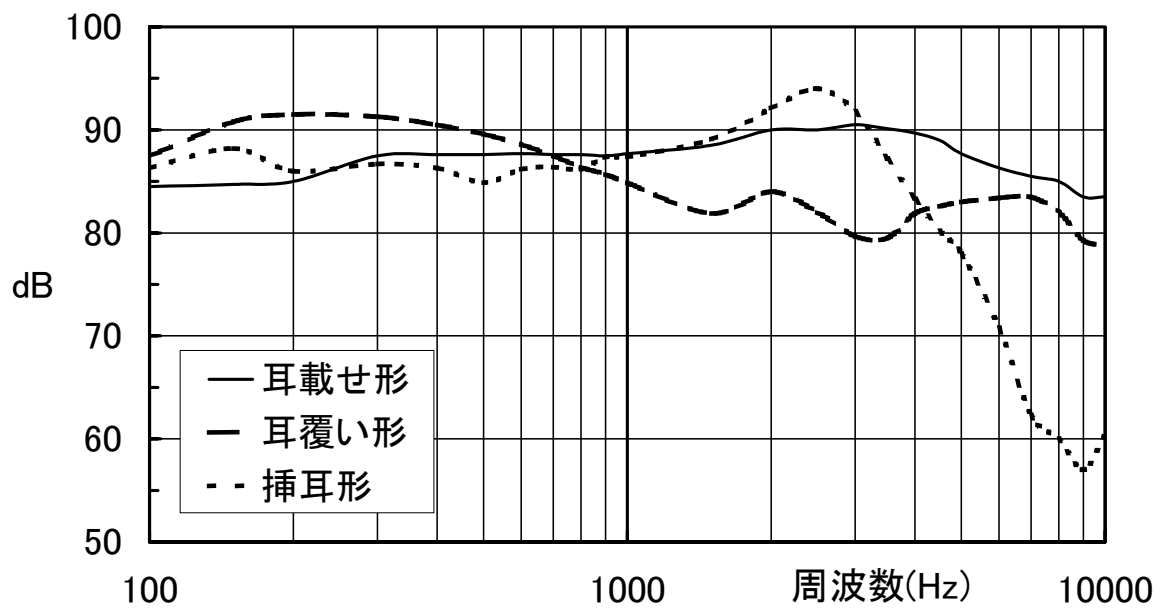

図 1 使用したイヤホンの定電圧特性（入力電圧 $100 \mathrm{mV}$ ) 
表 1 イヤホン別の SRT $\quad(\mathrm{n}=30)$

\begin{tabular}{|c|c|c|c|}
\hline & 耳載せ形 & 耳覆い形 & 挿耳形 \\
\hline & 平均 $\mathrm{SD}$ & 平均 $\mathrm{SD}$ & 平均 $\mathrm{SD}$ \\
\hline & dBSPL $d B$ & dBSPL $\mathrm{dB}$ & dBSPL dB \\
\hline \multirow{2}{*}{ 比例配分法 } & 12. 2 & 8.6 & 8.3 \\
\hline & \pm 2.3 & \pm 2.3 & \pm 2.9 \\
\hline \multirow{2}{*}{ Wilson 法 } & 12.9 & 9.0 & 8.3 \\
\hline & \pm 2.3 & \pm 1.8 & \pm 3.1 \\
\hline $\begin{array}{c}\text { ANSI S3. } 6 \\
\quad(1997)\end{array}$ & 20.0 & 19.0 & 12.5 \\
\hline
\end{tabular}

めた。

\section{結果}

\section{1.イヤホンごとの SRT}

耳載せ形・耳覆い形・挿耳形の各イヤホンで得ら れたSRTの測定結果は表1のと㧍りである。比例 配分法・Wilson 法ともに, 耳載せ形・耳覆い形・ 挿耳形の順で SRT の值が小さくなった。算出方法 による有意差は見られなかった。二つの算出方法の 平均值で表わすと，耳載せ形，耳覆い形，挿耳形人 ヤホンの SRT はそれぞれ，12.6dBSPL，8.8dBSPL, 8.3dBSPLであった。表 1 には参考のため，米国規 格協会（ANSI）S3. $6^{15)}$ に規定されている基準語音 了解閾值レベルを示した。語表が異なるため単純な 比較はできないが, 閾值の大きさの順序は今回の結 果と一致している。各イヤホンの基準值が ANSI の 值に比して小さくなったのは, アメリカの単語語表 に比し数字の方が聞き取りやすいためと思われる。

\section{2. 測定順序ごとの SRT}

順序効果の検討のため, 実施した順序・イヤホン 別に求めた SRT を表 2 に示す。比例配分法で求め た耳載せ形 1 回目と耳載せ形 2 回目の測定の平均値 の間にのみ対応のない $\mathrm{t}$ 検定（両側検定）で $5 \%$ 水 準にて有意差が認められた。他の条件では有意差を 認めなかったが，いずれも 1 回目と比較して 2 回目 の平均值が小さくなる傾向がみられた。

\section{考察}

1. 順序効果について

今回，比較のために測定した耳載せ形イヤホンの SRTの平均值は, 比例配分法でも Wilson 法でも,
現在の日本聴覚医学会の耳載せ形イヤホンの基準値 $14 \mathrm{~dB}^{12)}$ に比べ 1 〜 $2 \mathrm{~dB}$ 小さい值となった。(表 1 ) その原因としては，いずれのイヤホンでも 1 回目の 測定に比し 2 回目の測定での SRT が小さくなって いる（結果 2 ）ことより，順序効果が関与している 可能性が考えられる。今回使用した 3 つの語表は行 の順序を入れ替えてあるが，行内の 6 つの数字の順 序は入れ替えていないため, 被験者が数字の順番を 予想でき，そのため順序効果が現れた可能性が否定 できない。実際，1回目の測定の耳載せ形のSRT をみると，比例配分法では $13.4 \mathrm{~dB}$, Wilson 法では 14. $0 \mathrm{~dB}$ ，両算出方法の平均では， $13.7 \mathrm{dBSPL}$ と基 準值に近くなる結果が得られた。このとき（1 回目 の測定による時)，耳覆い形と挿耳形の SRT は，両 算出方法の平均でそれぞれ 8.9dBSPL，9.1dBSPL とほほ等しくなり, 耳載せ形に比し約 $5 \mathrm{~dB}$ 小さい SRTが得られた。

\section{2. 今回の測定の妥当性について}

今回の 3 種のイヤホンによるSRTの測定結果 が，各イヤホンの正常純音聴覚閾值と比較して妥当 か否かにつき検討した。SRT のレベルの語音では, 語音了解度指数 (speech intelligibility index, SII) が一定值，すなわち語音の聞き取りの手がかり全体 のうちある一定の割合が聞こえるようになると考え られるが, この割合は, 同じ語表についてはイヤホ ンの種類によらず一定であると考えられる。そうな っているか否かについて検討を試みた。SII は，各 周波数帯における語音のスペクトルレベルと基準内 部雑音スペクトルレベル (reference internal noise spectrum level, RINSL) の差から求められる。後者 は，正常耳の純音聴覚閾值に相当する音圧レベル 
表 2 イヤホン・測定順序別の SRT $(\mathrm{n}=10)$

\begin{tabular}{|c|c|c|c|c|c|c|c|c|c|}
\hline \multirow{2}{*}{ 比例配分法 } & \multicolumn{3}{|c|}{ 耳載せ形 } & \multicolumn{3}{|c|}{ 耳覆い形 } & \multicolumn{3}{|c|}{ 挿耳形 } \\
\hline & 1 回目 & 2 回目 & 3 回目 & 1 回目 & 2 回目 & 3 回目 & 1 回目 & 2 回目 & 3 回目 \\
\hline 平均值（dBSPL） & 13.4 & 11.1 & 12.0 & 8.9 & 8.0 & 8.8 & 9.4 & 8.2 & 7.3 \\
\hline $\mathrm{SD}(\mathrm{dB})$ & 2.4 & 2.1 & 2. 0 & 2.1 & 2.6 & 2.4 & 2.9 & 3.3 & 2.3 \\
\hline \multirow{2}{*}{ Wilson 法 } & \multicolumn{3}{|c|}{ 耳載せ形 } & \multicolumn{3}{|c|}{ 耳覆い形 } & \multicolumn{3}{|c|}{ 挿耳形 } \\
\hline & 1 回目 & 2 回目 & 3 回目 & 1 回目 & 2 回目 & 3 回目 & 1 回目 & 2 回目 & 3 回目 \\
\hline 平均值 (dBSPL) & 14.0 & 12. 0 & 12.8 & 8.8 & 8.7 & 9.4 & 8.8 & 8.4 & 7.6 \\
\hline $\mathrm{SD}(\mathrm{dB})$ & 2.8 & 1.5 & 2.1 & 1.6 & 2.1 & 1.7 & 3. 0 & 3.8 & 2.7 \\
\hline
\end{tabular}

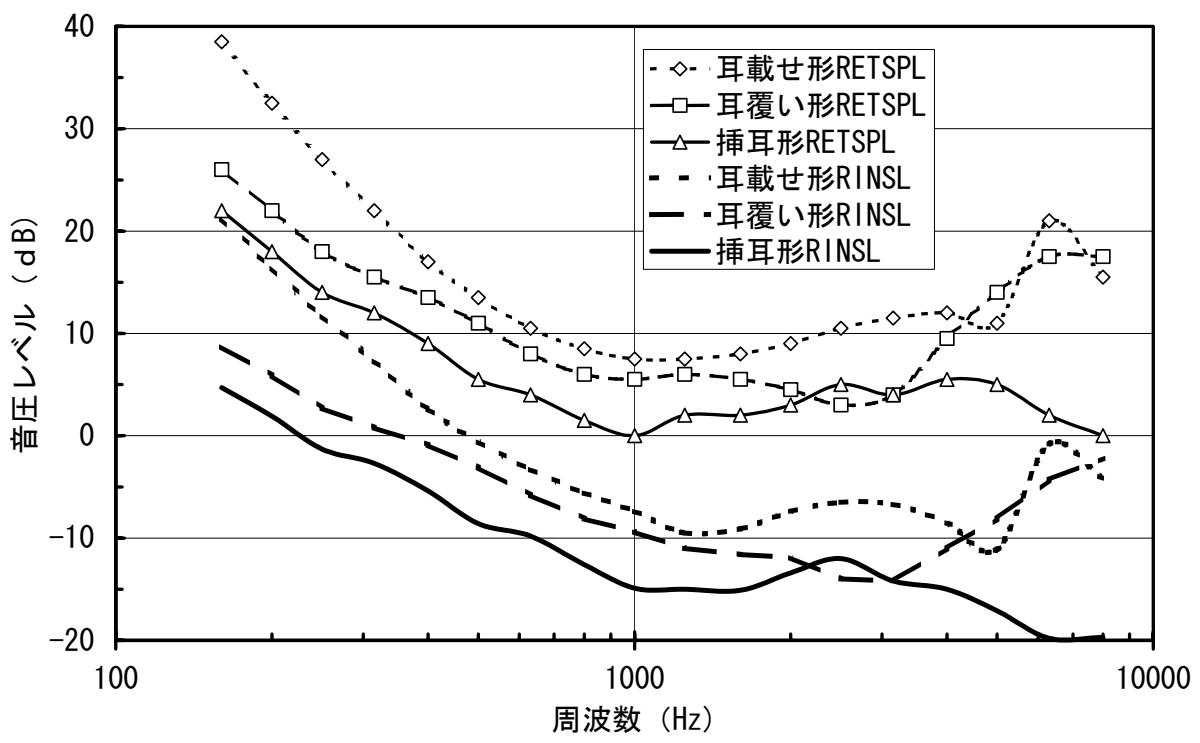

図2 三種のイヤホンの基準等価闇值音圧レベル（RETSPL）と 基準内部雑音スペクトルレベル（RINSL）

（基準等価間值音圧レベル，RETSPL）から臨界比 の $\mathrm{dB}$ 表示值を引いた值である ${ }^{16)}$ 。 RINSL は，正常 に比べてはるかに感度の良い仮想的な耳をこのスペ クトルレベルをもつ雑音でマスキングした場合に, その耳の純音の聴覚域值が基準等価域值音圧レベル となるような雑音のスペクトルレベルに相当する。 図 2 に三種類のイヤホンの RETSPL と RINSLを示 した。図 3 はイヤホンごとに, 閾值付近での語音の 長時間平均スペクトルとRINSLを比較したもので ある。今回耳覆い形と挿耳形は耳載せ形に比し約 5 $\mathrm{dB}$ 小さい SRT が得られたため，これに合わせて語 音のスペクトルのグラフは耳覆い形と挿耳形では耳 載せ形より $5 \mathrm{~dB}$ 下げてある。図 1 の定電圧特性の
影響を受け語音のスペクトル曲線の形はイヤホンに より少し異なっている。各々のイヤホンについて, 語音のスペクトル曲線と RINSL の曲線の間の部分 に存在する語音の情報（speech cue）が聞き取れる ことになる。図 3 を見ると各イヤホン間で, この部 分の面積には視覚的に大きな差のないことが分か る。すなわち, どのイヤホンも概ね同じ量の speech cue が聞き取れる語音レベルがSRTになったこと になる。多くの周波数で挿耳形より耳覆い形の方が RINSLの值が大きい（図 2) にも関わらず，2つ のイヤホンの SRT がほぼ等しくなったのは, 定電 圧特性の影響で，耳覆い形イヤホンで聞く場合の語 音スペクトルが低音域で大きく，その分耳覆い形イ 

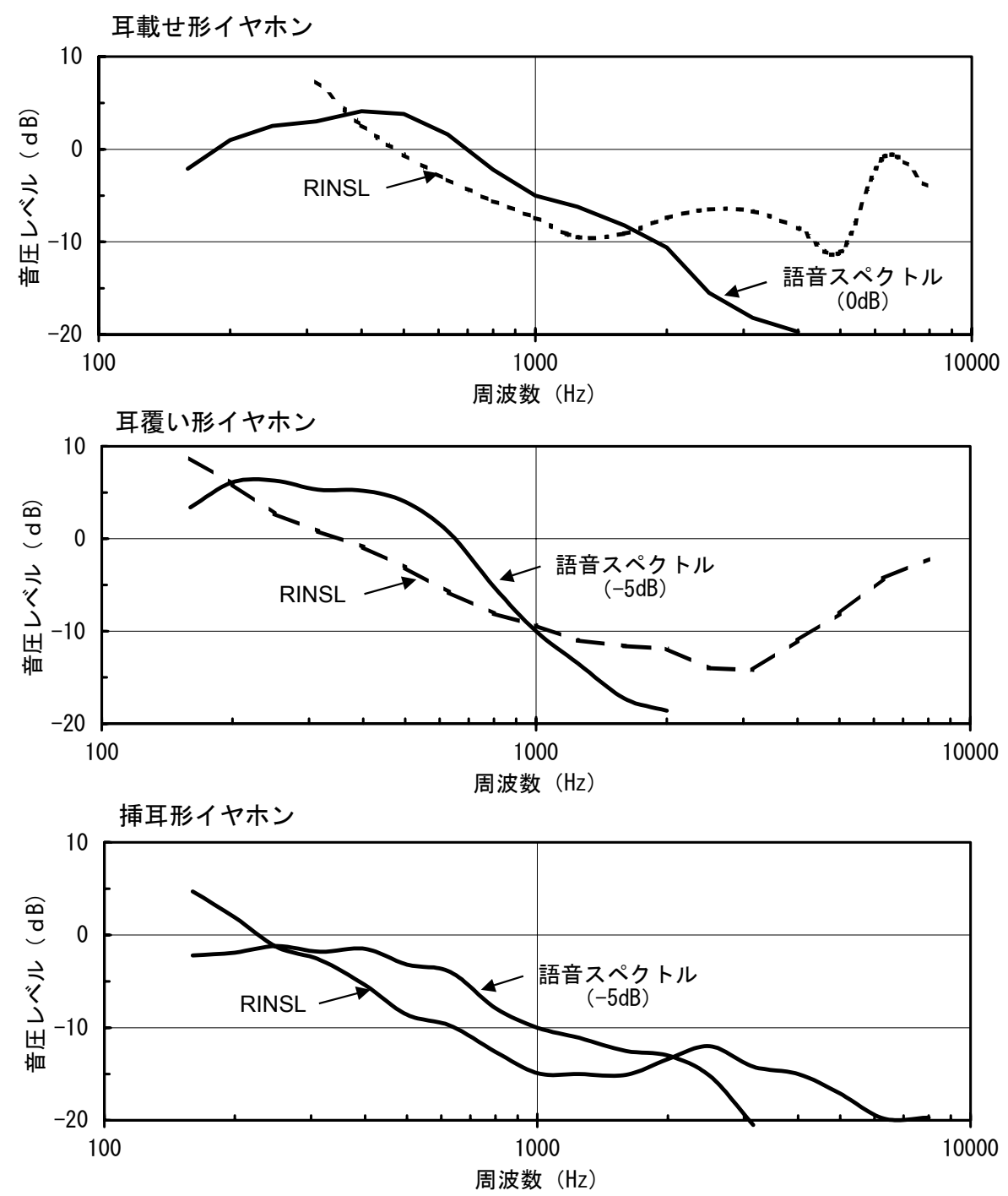

図3 閾值付近の語音の可聴範囲の比較

ヤホンで聞き取りやすくなったためと思われる。こ れらのことから, 今回の結果は各イヤホンの正常純 音聴覚閾值と矛盾しない結果と考えられる。

\section{まと め}

耳覆い形イヤホンと挿耳形イヤホンについて，語 音聴力検査の基準值の設定を目的に，正常耳の語音 了解閾值（SRT）を測定した。表 1 に示すSRTが 得られたが，この結果には順序効果が関与している 可能性が考えられた。1回目のみの測定による SRT は表 2 の通りで, 耳覆い形・插耳形イヤホンともお よそ9dBSPL という結果となった。この值は正常純 音聴覚閾值と比較して, 概ね妥当な值であると考え
られた。

順序効果については, 耳載せ形に強く表れた理由 も含めて不明な点もあり, 今後さらに検討が必要と 考えられる。順序効果はあったとしても 1 2dB で 臨床的にはあまり問題ないと思われるが, 通常 SRT は両耳とも検査を行うことを考えると，1回目の測 定值をもとに基準值を作るのが適当か否かについて も検討が必要であろう。

今回の実験では, イヤホン間の比較を重視して, 被験者内計画としたが, 順序効果があるとすれば, 被験者数を増やして被験者間計画に切り替えて新た に検討を行う必要があると考えられる。 


\section{Speech recognition threshold levels in nor- mal-hearing listeners using circumaural and insert earphones}

\author{
Mai Ogino ${ }^{1)}$, Toshimasa Matsuhira ${ }^{2)}$ \\ ${ }^{1)}$ Ishioka Circulatory and Neurosurgery Hospital \\ ${ }^{2)}$ School of Allied Health Sciences, Kitasato Uni- \\ versity
}

Monaural speech recognition thresholds (SRTs) for single digits of the 67-S speech audiometric test list were measured in 30 normal-hearing listeners wearing circumaural (SENNHEISER HDA 200), insert (EAR TONE 3A) or supra-aural（Rion AD-02) earphones, in order to determine the reference level for the first 2 types of earphones. The SRT of the last earphone was measured as control.

Data were collected using a within-subject design, in which each subject was tested using the different earphones, the sequence of use being counter-balanced. But, as, during the process of data analysis, a sequencing effect of lower SRTs in the second or the third measurement was partially observed, we reanalyzed the data using a betweensubject design with 3 groups consisting of 10 subjects each who were tested using each earphone for the first time.

The mean SRTs in the 10 subjects for the circumaural and insert earphones were 8.9 and 9.1 dBSPL, respectively, whereas the mean SRT for the supra-aural earphone was 13.7dBSPL, which almost corresponds to the 14dBSPL already established as the reference level.

When estimated from the reference internal noise spectrum levels, audible portions of the speech spectrum at the SRT levels for each earphone obtained in this study were similar, which seems to validate our results.

To establish the reference SRT levels for the two earphones, it is necessary to collect further data using an independent-group design with a larger number of test subjects and participation of test facilities.

\section{参考文献}

1）日本工業規格：オージオメータ一第 1 部：純音 オージオメー夕。JIS T1201-1：2000, 日本規格 協会, 東京, 2000

2 ) International Standard: Acoustics-Reference zero for the calibration of audiometric equipment-Part 2: Reference equivalent threshold sound pressure levels for pure tones and insert earphones. ISO 389-2, International Standards Organization, Geneva, 1994

3 ) International Standard: Acoustics-Reference zero for the calibration of audiometric equipment-Part 8: Reference equivalent threshold sound pressure levels for pure tones and circumaural earphones. ISO 389-8, International Standards Organization, Geneva, 2004

4) Draft International Standard: Acoustics-Audiometric test methods-Part 1: Basic pure-tone air and bone conduction threshold audiometry. ISO/DIS 8253-1, International Standards Organization, Geneva, 2008

5 ）鈴木陽一, 竹島久志 : 最小可聴域值と等ラウド ネス曲線をめぐる最近の話題。日本音響学会誌 58: 130-137, 2002

6 ）望月俊美，横山由姫乃，松平登志正：純音聴力 検査における耳載せ形と耳覆い形イヤホンの比 較。Otology Japan 17 : 209-213, 2007

7 ) Killion MC, Wilber LA, Gundmundson GI : Insert earphones for more interaural attenuation. Hearing Instruments 36 : 34, 1985

8) König E: On the use of hearing aid type earphones in clinical audiometry. Acta Otolaryngol. 55 : 331-341, 1962

9 ) Sklare DA, Denenberg LJ : Interaural attenuation for Tuberphone insert earphones. Ear and Hearing 8 : 298-300, 1987

10) International Standard : Acoustics-Reference zero for the calibration of audiometric equipment-Part 9: Preferred test conditions for the 
determination of reference hearing threshold levels. ISO 389-9, International Standards Organization, Geneva, 2009

11) International Standard: Acoustics-Audiometric test methods-Part 1: Basic pure tone air and bone conduction threshold audiometry. ISO 8253-1, International Standards Organization, Geneva, 1998

12) 日本聴覚医学会: 語音聴力検査法 (2003)。Audiology Japan 46 : 622-637, 2003

13 ) International Standard : Acoustics. - Audiometric test methods. - Part 2: Speech audiometry. ISO8253-3, International Standards Organization, Geneva, 1998

14) Wilson RH, Morgan DE, Dirks DD : A proposed SRT procedure and its precedent. J Speech Hear Dis : 184-191, 1973

15) American National Standard: American National Standard Specification for Audiometers.
ANSI S3. 6, American National Standard Institute, New York, 1996

16) American National Standard : American National Standard Methods for the Calculation of the Speech Intelligibility Index. ANSI S3. 5, American National Standard Institute, New York, 1997

（原稿受付 平成22.1.7）

別冊請求先： ₹ $311-3434$

茨城県小美玉市栗又四ヶ1768-29

医療法人 石岡脳神経外科病院 石岡 循環器科脳神経外科病院

荻野 真愛

\section{Reprint request :}

Mai Ogino

Isioka Circulatory and Neurosurgery Hospital

Kurimatasika 1768-29, Omitama, Ibaraki, 311-3434

Japan 